\title{
Effects of sea-level rise on barrier island groundwater system dynamics - ecohydrological implications
}

\author{
John P. Masterson, ${ }^{1 *}$ Michael N. Fienen, ${ }^{2}$ E. Robert Thieler, ${ }^{3}$ Dean B. Gesch, ${ }^{4}$ \\ Benjamin T. Gutierrez ${ }^{3}$ and Nathaniel G. Plant ${ }^{5}$ \\ ${ }^{1}$ U.S. Geological Survey, Northborough, MA, USA \\ ${ }^{2}$ U.S. Geological Survey, Middleton, WI, USA \\ ${ }^{3}$ U.S. Geological Survey, Woods Hole, MA, USA \\ ${ }^{4}$ U.S. Geological Survey, Sioux Falls, SD, USA \\ ${ }^{5}$ U.S. Geological Survey, St. Petersburg, FL, USA
}

\begin{abstract}
We used a numerical model to investigate how a barrier island groundwater system responds to increases of up to $60 \mathrm{~cm}$ in sea level. We found that a sea-level rise of $20 \mathrm{~cm}$ leads to substantial changes in the depth of the water table and the extent and depth of saltwater intrusion, which are key determinants in the establishment, distribution and succession of vegetation assemblages and habitat suitability in barrier islands ecosystems. In our simulations, increases in water-table height in areas with a shallow depth to water (or thin vadose zone) resulted in extensive groundwater inundation of land surface and a thinning of the underlying freshwater lens. We demonstrated the interdependence of the groundwater response to island morphology by evaluating changes at three sites. This interdependence can have a profound effect on ecosystem composition in these fragile coastal landscapes under long-term changing climatic conditions. Published 2013. This article is a U.S. Government work and is in the public domain in the USA.
\end{abstract}

KEY WORDS groundwater; barrier islands; sea-level rise; vadose zone; salinity; ecohydrology; vegetation distribution

Received 31 May 2013; Accepted 14 October 2013

\section{INTRODUCTION}

Barrier islands protect back-barrier estuaries and wetlands and provide critical groundwater-dependent habitats for migratory shorebirds and waterfowl as well as rare and endangered plant and animal species. They constitute about $10 \%$ of the world's coastlines (Stutz and Pilkey, 2011). As products of long-term sea-level rise over the past several thousand years, barrier islands continue to change in response to wind, wave, tide and sea-level fluctuations. A key determinant in shaping the ecological landscape in barrier islands is the thickness of the vadose zone - the unsaturated portion of the underlying groundwater system. Vadose zone thickness is a function of groundwater elevation and island morphology and, therefore, subject to changes in island characteristics. Understanding this relationship is critical to determining groundwater system response to sea-level rise and its resulting ecohydrological implications.

Sea level is projected to increase $20-200 \mathrm{~cm}$ from current levels by 2100 (Parris et al., 2012) and is one of the principal climate change concerns in coastal regions (Meehl et al., 2007; Nicholls and Cazenave, 2010). Barrier island systems are

*Correspondence to: John P. Masterson, New England Water Science Center, 10 Bearfoot Road, Northborough, MA 01532, USA.

E-mail: jpmaster@usgs.gov particularly vulnerable to the effects of sea-level rise given the inherently dynamic nature of these islands and their unique ecosystems. Ecologists have long understood the importance of vegetation assemblages in coastal ecosystem biodiversity (Ehrenfeld, 1990). Vegetation distribution typically follows a cross-shore zonation from ocean barrier beach to back-barrier bay of barren ocean-side beach, dune grasses, interior shrub thickets, upland maritime forests and eventually bay-side salt marshes. Key determinants in the establishment, distribution and succession of these vegetation assemblages are vadose zone thickness (depth to the water table) and groundwater salinity in the shallow coastal aquifers that underlie barrier island systems (Ehrenfeld, 1990; Johnson and Young, 1993; Young et al., 1994; Hayden et al., 1995; Kirwan et al., 2007; O’Connell et al., 2012; Aguilar et al., 2012) [Figure 1(A.)].

Vadose zone thickness affects the duration of root-zone saturation. Long-term changes of as little as $25 \mathrm{~cm}$ in water-table position affect the distribution of shrub thickets (Myrica cerifera) and emergent marsh vegetation (Cladium jamaicense Crantz) in interdunal swales (Rheinhardt and Fraser, 2001). Groundwater salinity also is considered a principal environmental factor controlling plant distribution across barrier islands particularly in the zonation of marshes and shrub thickets (Young et al., 1994, 2007; Hayden et al., 1995; Zinnert et al., 2011). Vegetation shifts 

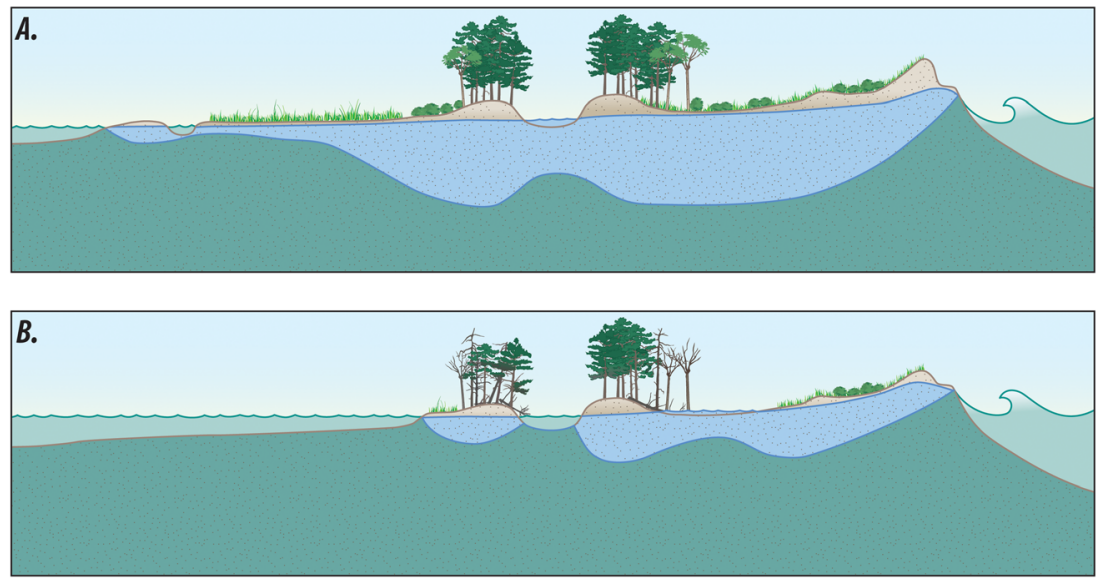

Figure 1. Sea-level rise can affect groundwater flow in barrier island aquifers by decreasing the vadose zone (shown in brown) and the freshwater lens thickness (shown in blue) as the water table rises in response to increases in sea level from current $(A$.) to future conditions $(B$.). These hydrologic responses are key determinants in the establishment, distribution and succession of vegetation assemblages and habitat suitability in barrier island systems.

in response to changes in vadose zone thickness and groundwater salinity can alter critical habitats and adversely affect the species that depend on them.

The viability of maritime forests in coastal areas also is highly dependent on vadose zone thickness and groundwater salinity in the underlying, shallow aquifer systems (Clark, 1986; Johnson and Young, 1993). Mature tree stands have been found to occupy lower land-surface altitudes than did their seedlings because, during the period from germination to seed production, suitable soil-moisture conditions shifted upslope in response to sea-level rise (Clark, 1986). Progressive saturation of the forest-rooting zone can reduce water absorption and limit growth through reduced gas exchange (Johnson and Young, 1993).

Coastal loblolly pine forests (Pinus taeda) require sufficient vadose zone thickness to enable new saplings to establish a foothold in coastal areas (Kirwan et al., 2007). A progressively thinner vadose zone thus limits forest sustainability, resulting in loss of forest habitat critical for many bird species (Ehrenfeld, 1990). Given the importance of vadose zone thickness and groundwater salinity on barrier island ecosystems, any processes that affect the groundwater flow system, such as sea-level rise, long-term droughts or increased wet periods, will likely affect ecosystem function and species diversity across the barrier island landscape.

Increases in sea-level position directly result in increases in water levels in shallow coastal aquifer systems and indirectly result in changes to groundwater discharge to surface water including ponds, streams and wetlands - and aquifer salinity (Sherif and Singh, 1999; Masterson and Garabedian, 2007; Werner and Simmons, 2009; Oude Essink et al., 2010). Although this hydrologic response can have wide-ranging ramifications in terms of human and ecosystem impacts, most of the attention to this response has been limited to densely populated, developed coastal areas and focused on potential impacts on drinking-water supplies from saltwater intrusion (Ferguson and Gleeson, 2012; Guha and Panday, 2012; Langevin and Zygnerski, 2013) and on subterranean infrastructure from groundwater inundation (Flood and Cahoon, 2011; Rotzoll and Fletcher, 2012). The ecohydrological impacts of sea-level rise are of great concern in largely undeveloped barrier island systems, yet the potential hydrologic response is poorly understood.

In barrier island aquifer systems with relatively thin vadose zones (typically <1 m) (Krantz, 2009; Banks et al., 2012), modest increases in water-table altitude and or decreases in land-surface altitude create the potential for the water table to intersect land surface resulting in newly saturated areas and increased groundwater discharge to ponds, streams and wetlands (Figure 1). Additionally, changes in groundwater salinity depend in part on the ability of the water table to rise in unison with rising sea level. In areas with relatively thin vadose zones, land surface limits water-table rise, thus decreasing water-level altitude relative to local sea level, resulting in a decrease in the depth to the underlying freshwater/saltwater interface and a reduction in the volume of the freshwater lens (Masterson and Garabedian, 2007; Werner and Simmons, 2009). Hence, the groundwater dynamics in these aquifer systems are affected directly by rising sea levels and indirectly by the morphological changes driven by sea-level rise.

\section{METHODS}

We developed a three-dimensional groundwater model using SEAWAT (Langevin et al., 2007) that is capable of simulating both fresh and saline groundwater flows to evaluate the flow system response to sea-level rise for Assateague Island, a $60-\mathrm{km}$-long barrier island on the US mid-Atlantic 


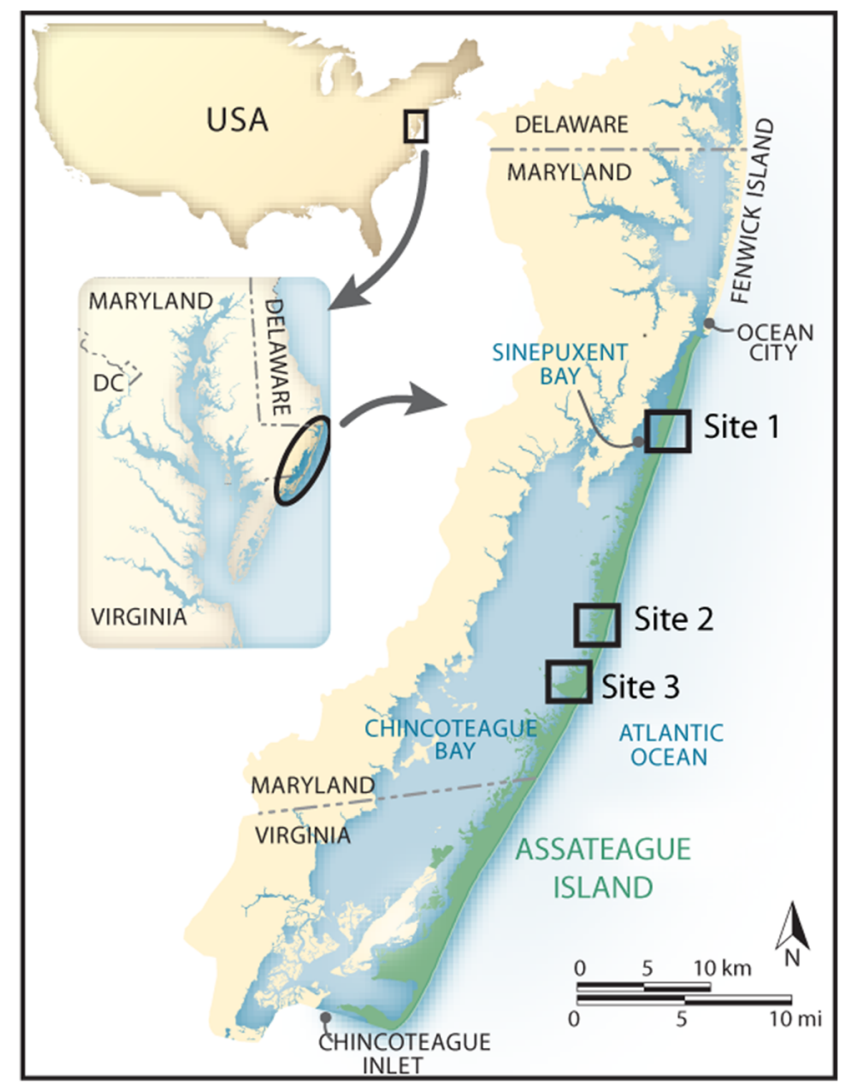

Figure 2. Assateague Island is one of the many barrier island systems that fringe the Atlantic coast of the USA. These systems are vitally important from a coastal ecological standpoint, providing critical habitats for migratory shorebirds and waterfowl as well as rare and endangered plant and animal species. (Figure used with the permission of the University of Maryland Center for Environmental Science-Integration and Application Network).

coast (Figure 2). Summary information for the groundwater model is given herein; additional details for this model can be found in Masterson et al. (2013). The model was constructed using geologic and spatial information to represent the island geometry, boundaries and physical properties. A lateral grid with a uniform spacing of $50 \mathrm{~m}$ was applied throughout the model. Vertically, the model was subdivided into ten layers, ranging in thickness from 0.5 to $12 \mathrm{~m}$ to a maximum depth of $30 \mathrm{~m}$, the depth to the upper portion of the underlying confined coastal plain deposits. The model was calibrated to observations of groundwater altitude and contrasts in salinity detected in boreholes by using data collected as part of our ongoing investigation (Banks et al., 2012).

Once the model was calibrated, we simulated three 36-year periods to assess the effect of sea-level rise on this aquifer system for the current rate of rise of $5.5 \mathrm{~mm} / \mathrm{yr}$ observed at the Ocean City, MD long-term tidal gage. The simulated sea-level position was adjusted upward and landward in $20-\mathrm{cm}$ increments to account for changes in the island geometry that would result from these changes in sea level. We report changes in vadose zone and freshwater lens thicknesses for increases in sea level of 20,40 and $60 \mathrm{~cm}$ above the current position. We conditioned our results to show only concentrations greater or less than 10 parts per thousand (ppt) salt for the contact between the fresh and salt groundwater flow systems. The $10 \mathrm{ppt}$ isohaline was selected somewhat arbitrarily to provide a means of clearly comparing the various hydrologic-conditions scenarios and should not be considered an ecological response threshold. The apparent sharpness of these depictions is not indicative of a truly sharp freshwater/ saltwater interface as some simulated diffusion and numerical dispersion (not shown here) results in a more gradational transition between freshwater and saltwater. Additional details on the modelling effort summarized here are provided in Masterson et al. (2013).

We selected Assateague Island because its geomorphology includes settings that are representative of most barrier islands worldwide (Stutz and Pilkey, 2011) and because it has been shown to be actively evolving in response to sea-level rise and other processes (Demarest and Leatherman, 1985). Future sea-level rise will impart clear morphological changes on the island, including changes in width and land-surface altitude. Some areas will become narrower as the ocean-side shoreline erodes or where back-barrier marsh growth is not sustained (Cahoon et al., 2009). Other areas may become wider as storm overwash and ephemeral tidal inlets move sediment 
across the island and into the back-barrier lagoon. Island height may increase or decrease depending on sediment availability, and changes in storm climatology that determine the length of time over which features like dunes can become established (FitzGerald et al., 2008; Gutierrez et al., 2009).

We use a simplified, single-value inundation model commonly referred to as a 'bathtub' model to simulate sealevel-rise effects on the emergent modelled area from the current mean high water level to $+60 \mathrm{~cm}$ above the current position in $20 \mathrm{~cm}$ increments. We recognize that this simple inundation model cannot account for the complex morphological changes expected with successive changes in sea-level position. However, we assume that this limitation is tractable for our simulated sea-level positions. We do not assign a temporal scale to these changes in sea-level position; we instead consider these increments representative of several points along a number of potential future sea-level-rise trajectories (Rahmstorf, 2007).

Our analysis considered the entire island, but we focus here on three locations (Figure 2) to illustrate the effects of sealevel rise on the vadose zone thickness and the thickness of the freshwater lens as the island morphology changes through three states that are representative of a wide variety of barrier islands. The three sites that we selected represent the evolutionary trajectory of the morphological response of barrier island systems to the effects of sea-level rise, a succession driven from sites 3 to 1 with increases in sea-level position (FitzGerald et al., 2008; Gutierrez et al., 2009).

The three morphological settings selected for our analysis have unique vegetation assemblages and distributions controlled in part by the prevailing hydrologic conditions, specifically vadose zone and freshwater lens thickness. The low, narrow overwash barrier morphology (site 1) and the single, large foredune with broad former flood tidal delta back-barrier morphology (site 2) consist primarily of dune grass and shrub thickets with submerged aquatic vegetation in the low-lying back-barrier marsh areas. The high, wide multiple-dune-ridge barrier morphology (site 3) contains inland maritime-forested areas that provide a diverse ecosystem on which myriad species depend.

\section{RESULTS}

Our results indicate a substantial change in the thickness of the underlying freshwater lens in response to sea-level rise at the three sites (Figures 3-5). The freshwater lens thins in response to cessation of freshwater input from aquifer recharge as island width decreases because of inundation from successive increases in sea-level position. In the remaining non-submerged portion of the island, the thickness of the underlying freshwater lens also decreased in areas where the water table approached the land surface; this outcome is referred to as a head-controlled condition and is based on the relation of water-table altitude to sea-level position that determines the depth to the freshwater/saltwater interface (Werner and Simmons, 2009). As a general rule, the Ghyben-Herzberg principle states that if the altitude of the water table above sea level $\left(\mathrm{z}_{\mathrm{w}}\right)$ is lowered by $1 \mathrm{~m}$, the depth to the freshwater/saltwater interface below sea level $\left(z_{\mathrm{s}}\right)$ decreases by $40 \mathrm{~m}: \mathrm{z}_{\mathrm{s}}=40 \mathrm{z}_{\mathrm{w}}$. In barrier islands with thin vadose zones, the water-table altitude cannot exceed the land surface, and therefore, as sea level continues to rise, there is a net decrease in water-table altitude relative to the local sealevel position. This condition, shown schematically in Figure 1, results in substantial thinning of the freshwater lens in areas where the water table is in contact with land surface.

Our simulations (Figures 3-5) clearly show changes in vadose zone thickness (brown to blue shading in map view) and groundwater salinity (blue to red shading in cross section) in response to sea-level rise. The low, narrow overwash barrier (site 1, Figure 3) is most affected by the increase in sea level from current to $+60 \mathrm{~cm}$ above current conditions. At the highest simulated sea-level position, the water table is in contact with land surface across most of this area, and the freshwater lens has all but disappeared. This morphological setting is the least stable of the three sites and is considered an endpoint in the evolutionary pathway of changes in island morphology and vegetation distribution and habitat (Ehrenfeld, 1990; FitzGerald et al., 2008). Changes to the groundwater system in response to sea-level rise at this site may be of secondary concern to those of continued coastal evolution and shoreline change considering the periodic storm overwash events that currently affect groundwater flow in this area.

The single, large foredune with broad former-flood tidal delta back-barrier site (site 2, Figure 4) is wider and has a thicker vadose zone and more developed freshwater lens than site 1 . Increases in sea level of $20-40 \mathrm{~cm}$ above current position result in minor inundation of the back-barrier area but substantially decrease the thickness of the underlying freshwater lens. The thin vadose zone beneath this backbarrier former-flood tidal delta restricts the water table from rising in unison with sea level resulting in substantial decrease in the thickness of the underlying freshwater lens. These results suggest that in this more morphologically stable setting, changes to the groundwater system from modest increases in sea-level position may exert greater influence on ecosystem composition and habitat suitability than from changes in island morphology.

The high, wide, multiple-dune-ridge barrier site (site 3, Figure 5) is considered representative of the most morphologically stable settings of barrier island systems and, therefore, should be most resilient to the effects of shoreline change from sea-level rise (FitzGerald et al., 2008; Gutierrez et al., 2009). Our simulated increases of 40-60 cm above the current sea-level position result in flooding of the low-lying interdunal wetland areas - a response that may be oversimplified by our inundation model (Cahoon et al., 2009). 


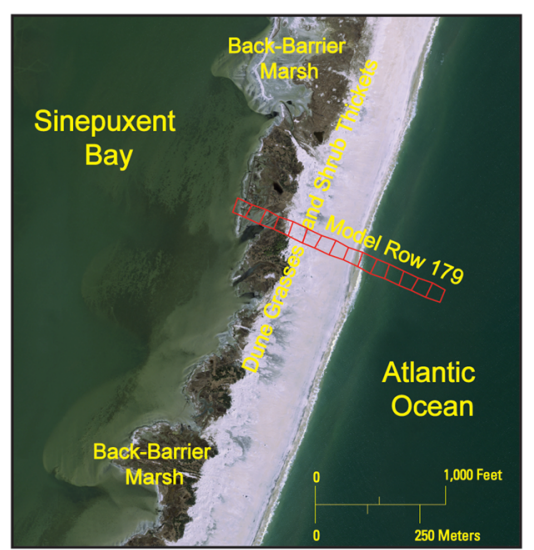

Map view of vadose zone thickness

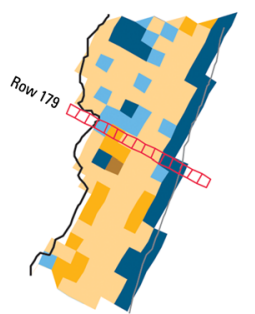

current

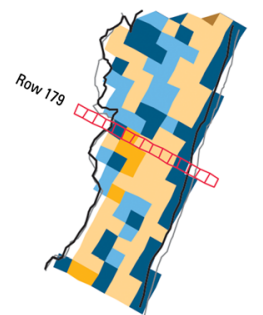

$+20 \mathrm{~cm}$
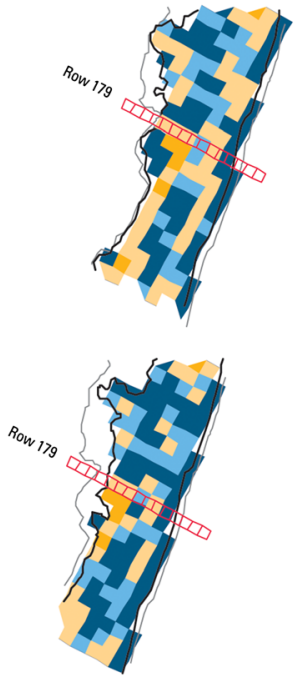

$+40 \mathrm{~cm}$

$+60 \mathrm{~cm}$

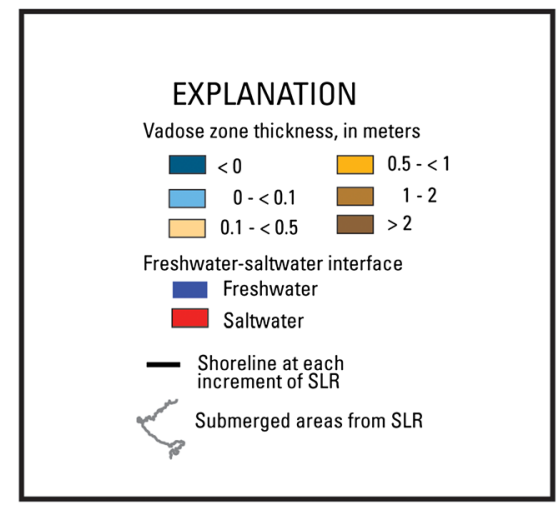

Freshwater lens thickness along model row 179

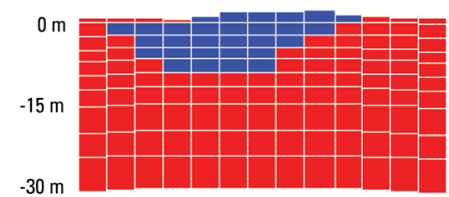

current sea-level position

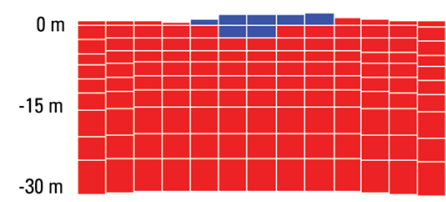

$20 \mathrm{~cm}$ above current sea-level position

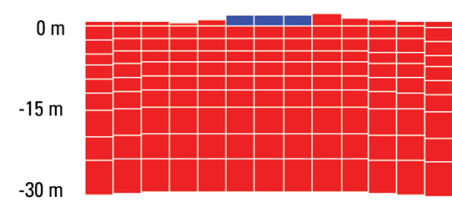

$40 \mathrm{~cm}$ above current sea-level position

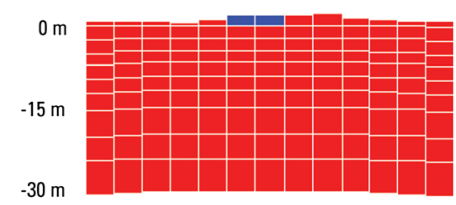

$60 \mathrm{~cm}$ above current sea-level position

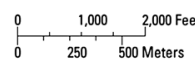

Vertical exaggeration $\times 20$

Figure 3. Successive changes in sea level to $+60 \mathrm{~cm}$ above current position at the low, narrow overwash barrier site (site 1) result in inundation of lowlying areas, an increase in the height of the water table, a decrease in vadose zone thickness (brown to blue shading in map view) and a decrease in the thickness of the underlying freshwater lens (blue to red shading in cross section).

The area behind the foredune remains non-submerged at these higher sea-level positions, but changes in vadose zone thickness result in a substantial thinning of the freshwater lens, which may limit freshwater availability and adversely affect this inland maritime-forested area and the diverse ecosystem that it supports. 

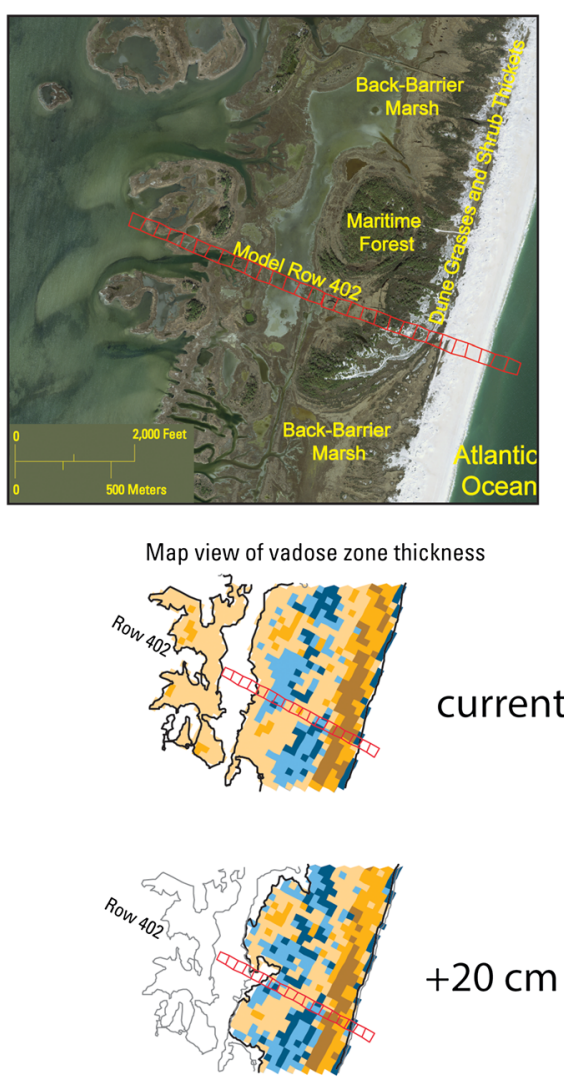

$+20 \mathrm{~cm}$

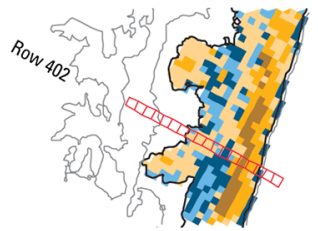

$+40 \mathrm{~cm}$

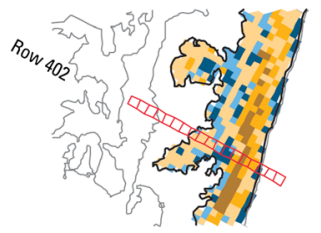

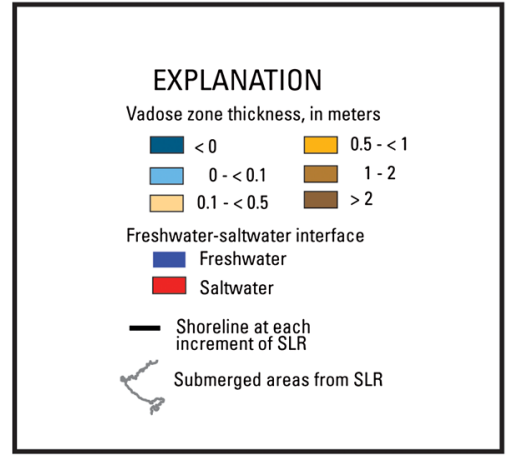

Freshwater lens thickness along model row 402
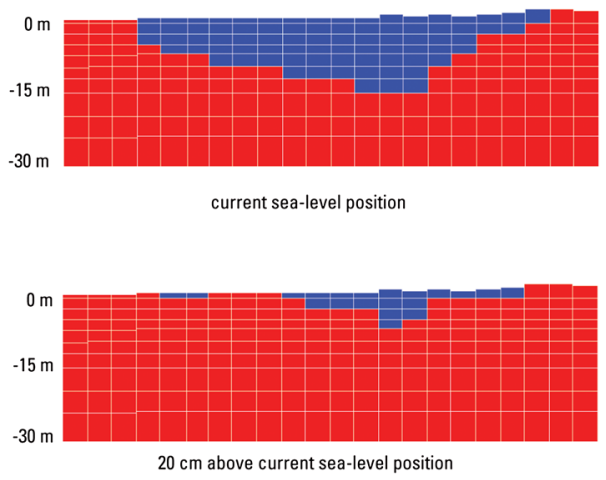

$20 \mathrm{~cm}$ above current sea-level position

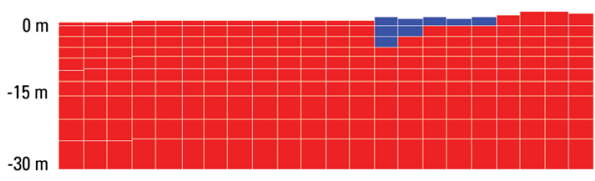

$40 \mathrm{~cm}$ above current sea-level position

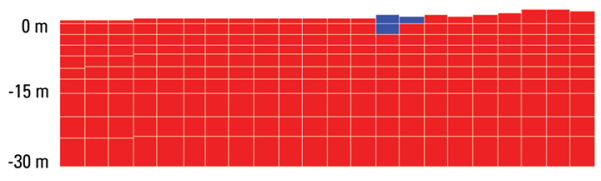

$60 \mathrm{~cm}$ above current sea-level position

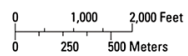

Vertical exaggeration $\times 20$

Figure 4. Successive changes in sea level to $+60 \mathrm{~cm}$ above current position at the single, large foredune with broad former flood tidal delta back-barrier site (site 2) result in inundation of low-lying areas, an increase in the height of the water table, a decrease in vadose zone thickness (brown to blue shading in map view) and a decrease in the thickness of the underlying freshwater lens (blue to red shading in cross section).

\section{DISCUSSION AND CONCLUSIONS}

Model results, such as those presented here, are key to developing landscape-scale models of vegetation and ecosystem evolution to predict sea-level-rise-driven succession and distribution changes across barrier islands. We analysed the groundwater flow system response to sea-level rise while mindful of the assumptions and limitations of our simple inundation modeling approach. Ideally, we would couple morphological models with our groundwater model to account for changes in island morphology, but island morphologic evolution models (FitzGerald et al., 2008) are currently insufficient to provide the necessary threedimensional framework for such modelling analyses. Instead, we focused on three representative island settings to explore the influence of island morphology on the 


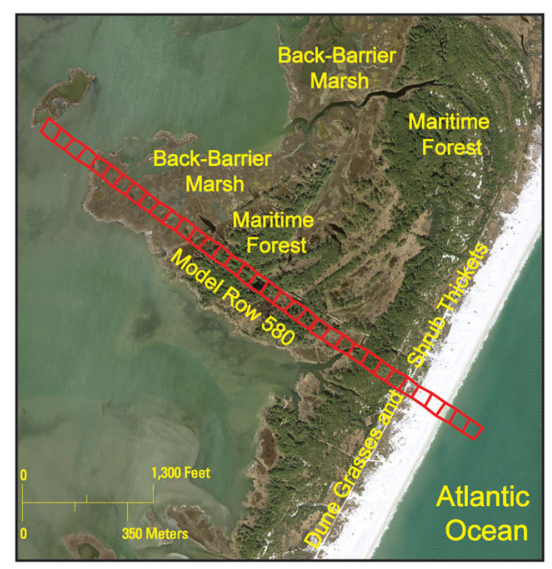

Map view of vadose zone thickness
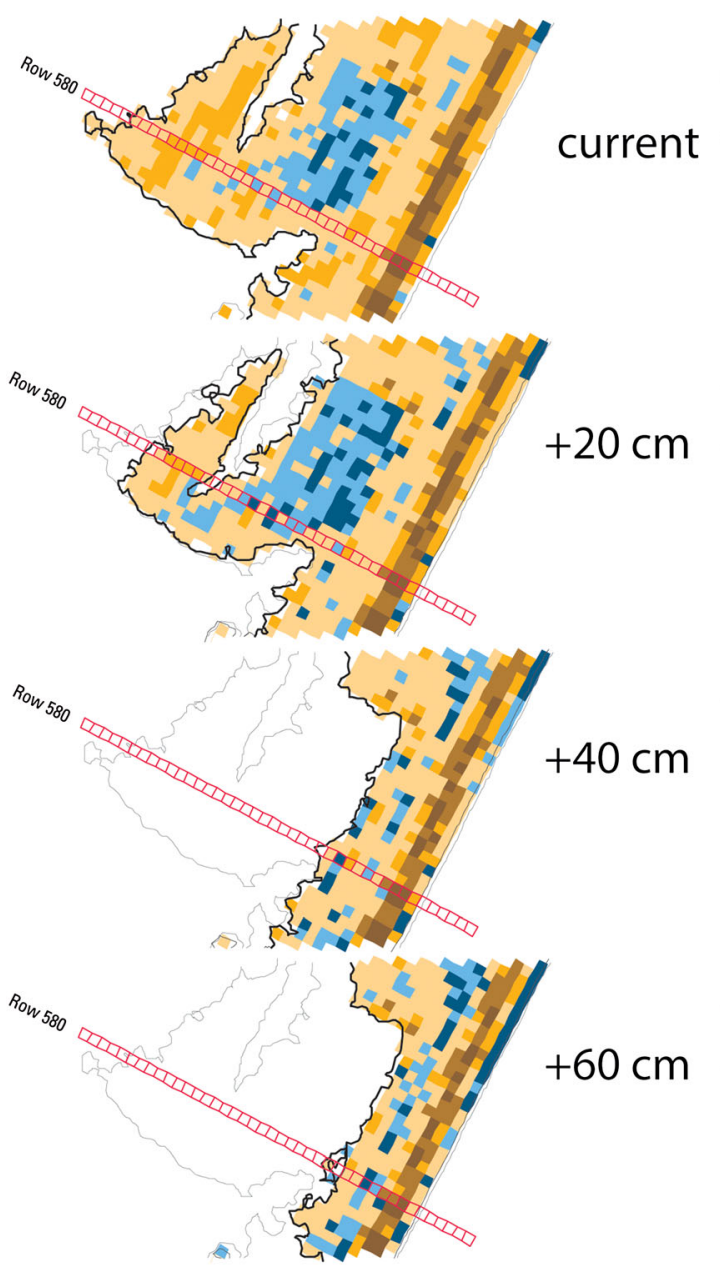

\section{EXPLANATION}

Vadose zone thickness, in meters

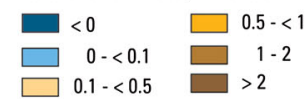

Freshwater-saltwater interface

Freshwater

$\square$ Saltwater

- Shoreline at each

Submerged areas from SLR

P

Freshwater lens thickness along model row 580

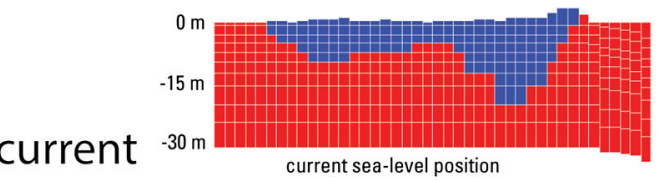

current sea-level position
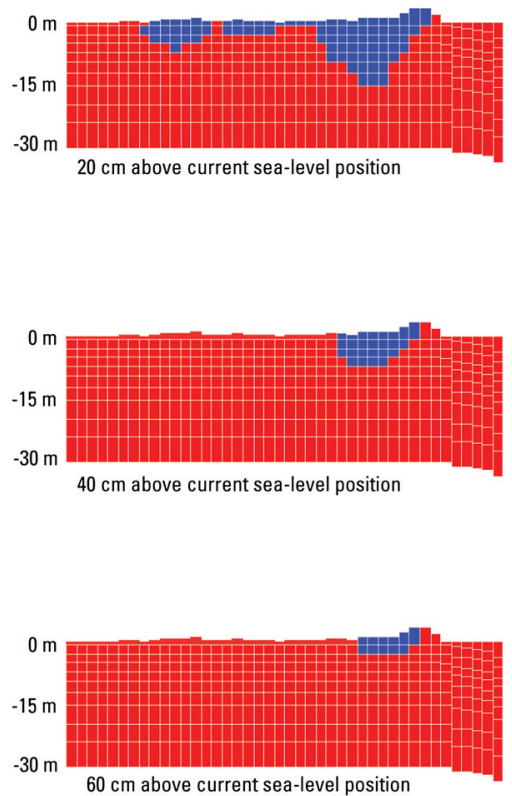

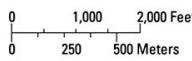

Vertical exaggeration $\times 20$

Figure 5. Successive changes in sea level to $+60 \mathrm{~cm}$ above current position at the high, wide, multiple-dune-ridge barrier site (site 3 ) result in inundation of low-lying areas, an increase in the height of the water table, a decrease in vadose zone thickness (brown to blue shading in map view) and a decrease in the thickness of the underlying freshwater lens (blue to red shading in cross section).

groundwater system response for modest to moderate changes in sea-level position.

We recognize that primary concerns of near-term sealevel rise in most low-lying coastal areas are focused on increased coastal flooding and shoreline change, whereas the groundwater response in coastal aquifers is thought to be less important and occur over a longer period of time. However, our results show that in barrier island systems 
with thin vadose zones, increases of as little as $20 \mathrm{~cm}$ in sea-level position can have substantial effects on the groundwater system and the ecosystems affected by changes in vadose zone thickness. These changes to the groundwater system will dictate ecosystem extent, structure and function as sea-level rises and the barrier-island morphology evolves into different states. This progression also has implications for current and future land-management decisions because the preferred choices for human infrastructure and development are often the most stable areas of the islands (i.e. site 3 ) and will be increasingly at odds with natural resource management desires for habitat and ecosystem continuity on these fragile coastal landscapes under long-term changing climatic conditions.

\section{ACKNOWLEDGEMENTS}

This work was supported by the USGS Climate and Land Use Mission Area, Research and Development Program and the USGS Natural Hazards Mission Area, Coastal and Marine Geology Program. The authors are grateful to the National Park Service and US Fish and Wildlife Service for collaboration, data and access to Assateague Island.

\section{REFERENCES}

Aguilar C, Zinnert JC, Polo MJ, Young DR. 2012. NDVI as an indicator for changes in water availability to woody vegetation. Ecological Indicators 23: 290-300.

Banks WSL, Masterson JP, Johnson CD. 2012. Well network installation and hydrogeologic data collection, Assateague Island national seashore, Worcester County, Maryland, 2010. Scientific Investigations Report 2012-5079, 52 p., USGS, Denver, Colorado.

Cahoon DR, Reed DJ, Kolker AS, Brinson MM, Stevenson JC, Riggs S, Christian R, Reyes E, Voss C, Kunz D. 2009. Coastal wetland sustainability. In: Coastal Sensitivity to Sea-Level Rise: A Focus on the Mid-Atlantic Region. A report by the U.S. Climate Change Science Program and the Subcommittee on Global Change Research, Titus JG (coordinating lead author), Anderson KE, Cahoon DR, Gesch DB, Gill SK, Gutierrez BT, Thieler ER, Williams SJ (lead authors). pp. 57-72, U.S. EPA, Washington D.C.

Clark JS. 1986. Coastal forest tree populations in a changing environment, southeastern Long Island, New York. Ecological Monographs 56: 259-277.

Demarest JM, Leatherman SP. 1985. Mainland influence on coastal transgression: Delmarva Peninsula. Marine Geology 63: 19-33.

Ehrenfeld JG. 1990. Dynamics and processes of barrier-island vegetation. Reviews in Aquatic Sciences 2: 437-480.

Ferguson G, Gleeson T. 2012. Vulnerability of coastal aquifers to groundwater use and climate change. Nature Climate Change 2: $342-345$

FitzGerald DM, Fenster MS, Argow BA, Buynevich IV. 2008. Coastal impacts due to sea-level rise. Annual Reviews in Earth and Planetary Science 36: 601-647.

Flood JF, Cahoon LB. 2011. Risks to coastal wastewater collection systems from sea-level rise and climate change. Journal of Coastal Research 27: 652-660.

Guha H, Panday S. 2012. Impacts of sea-level rise on groundwater salinity in a coastal community of south Florida. Journal of American Water Resources Association 48(3): 510-529.

Gutierrez BT, Williams SJ, Thieler ER. 2009. Ocean coasts. In: Coastal Sensitivity to Sea-Level Rise: A Focus on the Mid-Atlantic Region. A report by the U.S. Climate Change Science Program and the Subcommittee on Global Change Research, Titus JG (coordinating lead author), Anderson KE, Cahoon DR, Gesch DB, Gill SK, Gutierrez BT, Thieler ER, Williams SJ (lead authors). pp. 43-56, U.S. EPA, Washington D.C.

Hayden BP, Santos MCFV, Shao GF, Kochel RC. 1995. Geomorphological controls on coastal vegetation at the Virginia-Coast-Reserve. Geomorphology 13: 283-300.

Johnson SR, Young DR. 1993. Factors contributing to the decline of Pinus taeda on a Virginia barrier island. Bulletin of the Torrey Botanical Club 120: $431-438$.

Kirwan ML, Kirwan JL, Copenheaver CA. 2007. Dynamics of an estuarine forest and its response to rising sea level. Journal of Coastal Research 23: 457-463.

Krantz DE. 2009. A hydrogeomorphic map of Assateague Island National Seashore, Maryland and Virginia. Available at http://www.eeescience. utoledo.edu/Faculty/Krantz/download_files/NPS_Report. Assateague_Hydrogeomorphology.pdf.

Langevin CD, Thorne DJ, Dausman A, Sukop M, Guo W. 2007. Techniques and methods 6, chap. A22. SEAWAT Version 4: A Computer Program for Simulation of Multi-Species Solute and Heat Transport. USGS: Denver, Colorado; 78.

Langevin CD, Zygnerski M. 2013. Effect of sea-level rise on salt water intrusion near a coastal well field in southeastern Florida. Ground Water 51: 781-803.

Masterson JP, Fienen MN, Gesch DB, Carlson CS. 2013. Simulation of groundwater flow in the shallow aquifer of Assateague Island, MarylandVirginia. Open File Report 2013-1111, 32 pp., USGS, Denver, Colorado.

Masterson JP, Garabedian SP. 2007. Effects of sea-level rise on ground water flow in a coastal aquifer system. Ground Water 45: 209-217.

Meehl GA, Covey C, Taylor KE, Delworth T, Stouffer RJ, Latif M, McAvaney B, Mitchell JFB. 2007. Global Climate Projections, in Climate Change 2007: The Physical Science Basis: Contribution of Working Group I to the Fourth Assessment Report of the Intergovernmental Panel on Climate, chap. 10, Solomon SD, et al. (eds). Cambridge University Press: Cambridge, U. K.

Nicholls RJ, Cazenave A. 2010. Sea-level rise and its impact on coastal zones. Science 18: 1517-1520.

O'Connell MJ, Shugart HH, Okin GS. 2012. Measurement and monitoring of barrier island forest sensitivity to ecohydrological change using LIDAR remote sensing. Journal of Coastal Research 28: 793-810.

Oude Essink GHP, van Baaren ES, de Louw PGB. 2010. Effects of climate change on coastal groundwater systems: a modeling study in the Netherlands. Water Resources Research DOI: 10.1029/2009/ WR008719.

Parris AP, Bromirski PV, Burkett V, Cayan D, Culver M, Hall J, Horton R, Knuuti K, Moss R, Obeysekera J, Sallenger A, Weiss J. 2012. Global sea level rise scenarios for the U.S. national climate assessment. NOAA Technical Memo OAR CPO-1. 37.

Rahmstorf S. 2007. A semi-empirical approach to projecting future sealevel rise. Science 315: 368-370.

Rheinhardt RD, Fraser K. 2001. Relationship between hydrology and zonation of freshwater swale wetlands on lower Hatteras Island, North Carolina, USA. Wetlands 21: 265-273.

Rotzoll K, Fletcher CH. 2012. Assessment of groundwater inundation as a consequence of sea-level rise. Nature Climate Change DOI: 10.1038/ NCLIMATE1725.

Sherif MM, Singh VP. 1999. Effect of climate change on sea water intrusion in coastal aquifers. Hydrological Processes 13: 1277-1287.

Stutz ML, Pilkey OH. 2011. Open-ocean barrier islands: global influence of climatic, oceanographic, and depositional settings. Journal of Coastal Research 27: 207-222.

Werner AD, Simmons CT. 2009. Impact of sea-level rise on sea water intrusion in coastal aquifers. Ground Water 47: 197-204.

Young DR, Erickson DL, Semones SW. 1994. Salinity and the small-scale distribution of three barrier island shrubs. Canadian Journal of Botany 72: 1365-1372.

Young DR, Porter JH, Bachmann CM, Shao G, Fusina RA, Bowles JH, Korwan D, Donato TF. 2007. Cross-scale patterns in shrub thicket dynamics in the Virginia Barrier Complex. Ecosystems 10: 854-863.

Zinnert JC, Shiflett SA, Vick JK, Young DR. 2011. Woody vegetative cover dynamics in response to recent climate change on an Atlantic coast barrier island: a remote sensing approach. Geocarto International 26: 595-612. 